\title{
The Implementation of the conception of Friendship on the Basis of Comparative Structural-semantic Analysis of English and Russian Proverbs
}

\author{
Tatiana G. Orlova \\ Peoples' Friendship University of Russia (RUDN University) \\ 6, Miklukho-Maklaya street, Moscow, 117198, Russian Federation \\ orlova-tg@rudn.ru
}

\begin{abstract}
The article is devoted to the study of the conception of friendship based on the results of comparative structural-semantic analysis of English and Russian proverbs about friendship. The study includes two complementary steps. The first step consists in formulating the main aspects of the conception of friendship. The second consists in comparing fragments of this proverbial field, which made it possible to explore the implementation of eight aspects of the conception of friendship on the material studied. The clarification of similarities and differences made it possible to identify the specific national and cultural characters of thinking and mentality of the two non-related peoples towards understanding of friendship. The relevance of the study is determined by the novelty of the proposed approach to the study of the conception of friendship based on the comparative structural and semantic analysis of proverbs of two linguistic-cultural ethnic groups, as well as the insufficient knowledge of proverbs expressing the concept of "friendship" from the point of view of identifying their figurative and motivational basis, figurative means (metaphor, metonymy, comparison, personification, gradation, hyperbole, irony, allegory, antithesis), semantics of lexical components, syntactic structures (repetitions, parallelism, ellipsis, compression), expressive means, as well as rhythmic organization. There were selected and systematized similar and unique meanings of English and Russian proverbs as a result of research on the material of these languages. The analysis of these meanings allowed us to explore conception of friendship, thereby providing the basis for deeper rethinking both the conception and the proverbial material. As the part of the study there were observed differences in understanding of a person, personal relationships with others, mutual help, etc. These differences are largely due to the different origins of English and Russian proverbs. Most of the English proverbs are short sayings, which were formed under the influence of Latin expressions and quotations from Bible. Most of the Russian proverbs are peasant by origin and therefore they are closely connected with a specific and imaginative perception of the world. Their expressiveness is much higher at the expense of using the means of oral folk creativity. This analysis made it possible to reveal the role of linguistic means in expressing the mentality of the representatives of both peoples.
\end{abstract}

Keywords: conception, English proverb, Russian proverb, friendship, comparative analysis, structural-semantic analysis, figurative structure, mentality

(C) Орлова Т.Г., 2020

This work is licensed under a Creative Commons Attribution 4.0 International License https://creativecommons.org/licenses/by/4.0/ 


\title{
Acknowledgment:
}

The publication has been prepared with the support of the RUDN University Program "5-100".

\section{Article history:}

Received: 10.01.2020

Accepted: 15.02 .2020

\section{For citation:}

Orlova, T.G. (2020). The Implementation of the conception of Friendship on the Basis of Comparative Structural-semantic Analysis of English and Russian Proverbs. RUDN Journal of Language Studies, Semiotics and Semantics, 11(2), 301-318. doi: 10.22363/2313-2299-2020-11-2301-318

Удк [811.111:811.161.1]'373:398.91

\section{Реализация концепции дружбы на материале сопоставительного структурно-семантического анализа английских и русских пословиц}

\author{
Т.Г. Орлова \\ Российский университет дружбы народов \\ 117198, Российская Федераиия, Москва, ул. Миклухо-Маклая, д. 6 \\ orlova-tg@rudn.ru
}

\begin{abstract}
Статья посвящена сопоставительному структурно-семантическому анализу концепции дружба на материале английских и русских пословиц о дружбе. Исследование включает в себя два взаимодополняющих этапа. Первый этап состоит в формулировании основных аспектов концепции дружбы. Второй этап состоит в сопоставлении фрагментов данного пословичного поля, что позволило проследить реализации восьми аспектов концепции дружбы на исследованном материале. Уточнение найденных сходств и различий дало возможность выявить своеобразие образного мышления и особенности национального характера двух неблизкородственных народов в отношении понимания дружбы. Актуальность исследования определяется новизной предложенного подхода к изучению концепции дружбы на материале сопоставительного структурносемантического анализа пословиц двух лингвокультурных этносов, а также недостаточной изученностью пословиц, выражающих концепт «дружба» с точки зрения выявления их образномотивационной основы, художественных приемов (метафоры, метонимии, сравнения, олицетворения, градации, гиперболы, иронии, аллегории, антитезы), семантики лексических компонентов, синтаксических структур (повторы, параллелизм, эллипсис, компрессия), эмоциональноэкспрессивных средств, а также ритмической организации. В результате исследования на материале указанных языков были отобраны и систематизированы сходные и уникальные значения английских и русских пословиц. Анализ этих значений позволил раскрыть концепцию дружбы, дав тем самым основу для более глубокого переосмысления как самой концепции, так и пословичного материала. В ходе анализа были прослежены отличия в представлении о человеке, его взаимоотношениях с другими людьми, о взаимопомощи и т.д. Эти отличия в большей мере обусловлены различным происхождением английских и русских пословиц. Так, большая часть английских пословиц представляет собой краткие изречения, которые сформировались под влиянием латинских выражений и библейских цитат. Русские пословицы в большей мере имеют крестьянское происхождение и потому тесно связаны с конкретно-образным мировосприятием. Их экспрессивность намного выше за счет использования средств устного народного творчества.
\end{abstract}


Данный анализ позволил определить роль языковых средств в выражении менталитета представителей двух народов.

Ключевые слова: концепция, английская пословица, русская пословица, дружба, сопоставительный анализ, структурно-семантический анализ, образная структура, менталитет

\section{Благодарность:}

Публикация подготовлена при поддержке Программы РУДН «5-100».

\section{История статьи:}

Дата поступления: 10.01.2020

Дата приема в печать: 15.02.2020

\section{Для цитирования:}

Орлова Т.Г. Реализация концепции дружбы на материале сопоставительного структурносемантического анализа английских и русских пословиц // Вестник Российского университета дружбы народов. Серия: Теория языка. Семиотика. Семантика. 2020. Т. 11. nо 2. С. $301-$ 318. doi: 10.22363/2313-2299-2020-11-2-301-318

\section{Introduction}

The conception as an act of grasping, understanding and comprehending meanings during the discussion and the conflict of interpretations, as well as its result, presented in a variety of concepts [1], attracts a great interest in the humanities - in linguistics, it can be seen in the development of the linguo-cognitive approach and increased attention to comparative studies. According to a fair remark by A. Vezhbitskaya, "... linguistic data turn out to be critical in identifying fundamental models of thinking in various groups of people" [2. P. 54]. This premise explains the growing attention to the sociocultural potential of linguistic and speech units, when social phenomena are more fully revealed on the basis of linguistic patterns, and this aspect is defined as fundamental for humanitarian knowledge [3. P. 9]. In this regard, in modern linguistics the issue of the phraseological composition of the language as a means of interpreting the culture of peoples is becoming increasingly relevant, for which purpose "the human factor in the language vs the language factor in man is moving into the focus of attention of linguistic studies" [4. P. 9].

From these positions we must pay a special attention to such phenomena that avoid a strict definition and require a more flexible conceptual approach, for example, friendship [5. P. 1]. Friendship is an important phenomenon of human culture, a special kind of relationship between people; it is an "inexhaustible topic, the need for reflection on it arises constantly. Each new research can give a new point of view, a new look and the possibility of a new understanding" [6. P. 15-16]. The relevance of the study of the paremiological fund, among other matters, is associated with the relevance of the issue of national identity in the modern world [7]. The analysis of English and Russian proverbs about friendship, on the one hand, helps to explore more fully the phenomenon of friendship, on the other hand, helps to see the characteristics of perception and evaluation of its components and essential features by each peoples.

The article considers proverbs that compose the oldest fund of the phraseological system and reflect most vividly the national and cultural identity and mentality of 
both peoples. Following E.V. Ivanova, who generalized the definitions of the proverb given by foreign scholars, we will adhere this definition of proverb: "A proverb is a saying that expresses folk wisdom, tested by the experience of previous generations $<\ldots>$ it has a didactic function, an impetus to follow certain moral standards" [8. P. 11]. A great contribution to the development and study of the theory of phraseology and proverbs was made by such linguists as V.V. Vinogradov, A.V. Kunin, G.L. Permyakov, V.P. Zhukov, N.D. Arutyunova, N.L. Kovshova, Y.I. Levin et al.

Comparative studies in linguistics have become increasingly important and, to a greater extent, the comparison of phraseological units. "It is the comparative aspect of the systematic study of phraseology that is of great interest both for the development of the general theory of phraseology and for the study of general and distinctive features of the languages studied" [9. P. 3]. A contrastive analysis of paroemias contributes to the comparative study of languages and helps to identify cross-language universals. "A comparative description of semantic fields (of paroemias - T. Orlova) makes it possible to identify ethnic logic that represents differences in mental patterns of the studied linguistic-cultural communities" [10. P. 15]. So, the main, distinctive idea of the article that supplements known approaches is elucidation of the conception of friendship by a comparison of the proverbs of the English and Russian languages about friendship. The purpose of the article, therefore, is to identify the semantic groups of English and Russian proverbs representing the phenomenon of friendship; to explore general and specific features of proverbs of compared languages, identify linguistic and extralinguistic factors that determine similarity and differences in relation to their figurative meaning and semantics; to formulate general aspects of the conception of friendship and to trace their representation on the material received.

\section{Literature review}

The views that are relevant to our study on the problem of friendship conceptualization take shape in the framework of the review in four aspects. It is general categorization of friendship as a phenomenon, including the identification of linguistic patterns; representation of this phenomenon, taking into account the consistency of the language; a variety of manifestations in the representation of a multifaceted phenomenon; and the representation of the phenomenon of friendship in a proverbial space.

The first aspect that realizes a modern view on the problem is the general categorization of friendship as a phenomenon. It is significant that both the practical and theoretical sides of the problem are revealed with the participation of linguistic material and / or with linguistic implications, as, for example, in the work of E.E. Smith [11] or theoretical treatment of A. Maslow [12], and the studying of anthropology of friendship begins with questions of etymology [13]. Judging by research practice, the main directions in the general categorization of friendship as a phenomenon are the identification of the types of subjects entering into these relations [14. P. 174], and the allocation of research space when internal (emotional and sensual) or external (socio-economic and political) aspects of friendships are focused on [15. P. 492]. The possible adjunction of friendship and existential loneliness, revealed in the latest philological studies [16. P. 225], also matters. 
The second aspect of the review is the representation of the phenomenon of friendship, taking into account the systematic character of the language. We can see an example of this approach in the treatise that has become a classic of linguistics: Y.S. Stepanov, quoting M. Prishvin, draws attention to the etymological side of the linguistic system: “... In these words, Prishvin intuitively captures the etymology of the word friend: it is "the other self" [17. P. 582]. V.V. Dementiev considers the communicative dimension of the concept of "friendship" [18], and O.Y. Lukashkova analyzes the structure of the concepts "enemy" and "friend" through mutual comparison in the system of the language [19]. A linguistic-cultural dominant is noticeable in the study of the phenomenon in the language system. The work of M. Khizova shows an example of this approach with the indicative correlation of languages and cultures: "linguoculturology as one of the promising areas of sociocultural analytics" [20. P. 7] implicates the investigated problem in this aspect.

The third aspect of the categorization of the phenomenon naturally follows from the previous one. It is the variety of manifestations in the representation of a multifaceted phenomenon. A typical example is the work of Delaney T. and Madigan T., in which the authors investigated a wide range of modern types of friendship, from the so-called close friendship to virtual one [21]. For our study, however, the works covering various conceptual, emotional, communicative spheres are relevant [22]. As the review shows, it becomes possible to explain approximations of evaluative conceptualization of friendship in very different communicative practices on the basis of such an approach, and such a conceptualization is close to paroemias in the terms of linguistic essence.

The fourth aspect that is relevant for our view on the problem is exploration of the representation of the phenomenon of friendship in the proverbial space, that considers proverbial space as a sphere associated with the phenomenon of friendship by mutual cognitive basis [23. P. 7]. In a special linguistic study of the phenomenon of friendship in the Russian linguistic world-image A.D. Shmelev, among other things, relies on rich proverbial material [24]. The works based on the analysis of proverbs acquire a special character: for example, František Čermák conducts research on the material of proverbs of different languages using the international proverb dictionary [25]. This situation encourages to focus specifically on the identified aspect in the subsequent analysis, since the subject (groups of proverbs of certain languages) and the research method becomes critical for the result.

\section{Materials and methods}

Applied methods are contingent to the multidimensionality of the problem and complement each other. At the same time, our attention is focused on "systemology as a source and an integral part of the linguistic methodology" [26. P. 151]. The following main research methods were used in accordance to our goal: method of comparative phraseology, which was carried out in the structural-semantic and component aspects; descriptive method; functional stylistic analysis. Also we used principles of cognitive analysis, as well as elements of the method of hermeneutic interpretation. Cognitive analysis involved mainly compatible "methods of analysis of concepts and 
methods of analysis of categories" [26. P. 465]. The methodology of comparative structural-semantic analysis is promising in the process of identifying peculiar facts of language and culture, as well as clarification of the specifics of thinking and world perception of various peoples. The effectiveness of this methodology has been confirmed in a variety of ways by lexicographical verification, including one made on the material of proverbs [27].

These characteristics require a closer look at the object of study, English and Russian proverbs correlated to the phenomenon of friendship. The source of empirical material was the dictionaries of proverbs of Russian and English languages [28 - 32]. The reference method in the work with the proverbial material was the continuous sampling method. For the study 44 English and 56 Russian proverbs were selected.

The unity of methods is implemented in a certain sequence. The observation is applied at the stage of primary studying the problem space and correlates with the postulates of the descriptive method. The key aspects of the concept of friendship are discovered through the use of the principles of systematic approach and dialectical method. The previously mentioned types of analysis are used in appropriate combination. They provide the basis for generalizations, including schematized ones, defined in the framework of the "modeling method" [26. P. 312].

\section{Research results}

The concept of friendship is revealed in eight main implementations, which were formulated in the process of initial analysis of the semantic content of proverbs. The study of friendship as a type of relationship is based on the consideration of the basic principles of human relationships. Along with the desire of people for unification, we observe a desire for individualization; this contradiction is removed directly in the phenomenon of friendship. Friendships are classified and divided into subgroups; of all the possible grounds for classification, we are interested in the most universal, associated with the concept of "real" friendship. This classification basis is interesting precisely because we reveal the implementation of this aspect of the conception on the proverbial material. The traits that distinguish a true friend and how a friend becomes real mark another aspect of the conception of friendship. The key, most valuable properties of friends, the position of friendship in the value hierarchy and the strength of friendly ties complete our circle of interests.

The first of eight implementations, representing a separate aspect of the concept of friendship on the considered material, points to cooperation and mutual aid as a characteristic feature of the human community. Since ancient times, it was difficult for a person alone to cope with harsh living conditions - it is easier to overcome difficulties together. Proverbs of this semantic group are widely represented both in English and Russian, they belong to the oldest paroemiological layer. These proverbs contain moral priorities and, therefore, are very important for determinating the characteristic features of the national-cultural identity of both peoples. This group contains the following English proverbs: Two heads are better than one; Four eyes see more than two; A trouble shared is a trouble halved; One man, no man, etymologically tracing its origin to the Latin expression Unus vir nullus vir; There is safety in 
numbers; In the multitude of councelors there is safety, the proverb of biblical origin, which means that "collective responsibility is less dangerous than individual responsibility." The Russian proverbs of this group are: $У_{\mathcal{M}}$ хорошо, а два лучше 'Onе mind is good, but two are better'; Одна голова хоромо, а две лучше 'One head is good, but two are better'; Одна головня и в печи гаснет, а две и в поле курятся 'One firebrand goes out in the oven, and two burn in the field'; Один в поле не воин 'One cannot conquer alone'; Артель воюет, а один горюет 'The gang is fighting, and one is grieving'; В единении - сила 'There is strength in unity'; $C$ мира по нитке, голому - рубаха 'A single thread from everyone, and there's a shirt for a naked one'.

The comparison shows that two English and two Russian proverbs are very expressive due to metaphorization, which is based on somatisms: in the English proverb, four eyes - two eyes, two heads - one head, in the Russian proverb (один) ум - два (ума) 'one mind — two minds', одна голова - две (головы) 'one head - two heads'. The last three English proverbs are maxims - short sayings, coming from the Latin expression, quotes from the Bible. They use more neutral vocabulary. Russian proverbs are expressive due to the fact that the generalized meaning in them is expressed in metaphorical and concretized forms, the lexical components of which are associated with peasant life: головня 'firebrand', печь 'oven', поле 'field', as well as folk-speaking vocabulary: курятся 'burn', горюет 'is grieving'. Russian proverb В единении - сила 'There is strength in unity' is equivalent to English proverbs, which are based on Latin sayings. In the Russian proverb Один в поле не воин 'One cannot conquer alone' reflects the historical realities of Russian life, when a Russian man had to fight a lot. The last Russian proverb C мира по нит-

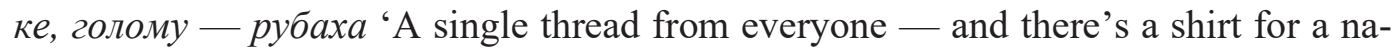
ked one' expresses the idea of mutual help. O.G. Dubrovskaya calls such proverbs "the proverbs of national linguistic mentality of the first type", the units of "unique cultural connotation" [33. P. 7]. They have no analogue in English and reflect the mentality of Russian people. "There is a generally accepted opinion about collectivism as a characteristic and most striking feature of the Russian archetype. $<\ldots>$ Sometimes this quality of Russians is also called "a sense of brotherhood." Russians themselves do not deny this value: "Good brotherhood is more valuable than wealth." Sometimes it causes outright envy and admiration among Europeans suffering from loneliness" [34. P. 155-156].

The regular nature of the discovered phenomenon, implementing the concept of friendship, is also supported by a systemic counterbalance, the semantic opposite. So, in the English language there is a proverb that points to the individualism of the British: Every man for himself. This proverb also has a unique cultural connotation and reflects the Englishman's mentality, his independence. The comparison of proverbs unique for each language allows us to draw a corresponding analogy with the forms of human sociality, represented, in particular, in the work of F. Tönnies with the concepts of "community" and "society": "Human wills relate in different ways to each other ... This relation itself and thus communication is understood either as real and organic life (this is the essence of community) or as an ideal and mechanical for- 
mation (this is the concept of society)" [35. P. 9]. The aforementioned Russian proverb through the idea of mutual help in the situation, which is difficult for one person (naked), but not for all members of the community (which could be the situation of a battle with an enemy, for example) postulates rather high level of closeness within this community, in fact, their unity: the problem of one member becomes a common problem. The English proverb claims the absence of the necessary essential connection between people: each person must solve his own problems.

The second of the implementations, which points out an internal contradiction of the concept of friendship, is reflected in the following group of English proverbs with unique meaning. They are about the need to maintain a distance in friendship: $A$ hedge between keeps friendship green; Familiarity breeds contempt. The first proverb is expressive due to the use of the colour epithet green, which rhymes with the word between - it contributes to its expressiveness and quick memorization. The second is an aphorism, a philosophical generalization. It contains neutral vocabulary and is devoid of expression. These proverbs have no analogues in the Russian language and reflect the mentality of the British, who believe that the closer you know a person, the more you see his or her flaws, and the initial admiration is often replaced by disappointment and neglect.

The third implementation, which directly reveals friendship as a complex entity, contains elements of integration of the first two groups, removing the contradiction found in the second one. It presents general characteristics of friendship as a type of closest non-related relationship between people, which is reflected in the corresponding groups of proverbs in both languages. The English proverbs of this group are: The only unsinkable ship is friendship; A true friend is the best possession in the world; Friendship, like phosphorus, shines brightest when all around is dark; A faithful friend is a medicine of life; It is better to be in chains with friends, than to be in a garden with strangers. These English proverbs correspond to Russian: Дерево крепче корнями, а человек - друзьями 'A tree is stronger in its roots, and a man is stronger in friends'; Друг - иенный клад, недругу никто не рад 'A friend is a valuable treasure, no one is happy with an enemy'; Человек без друзей - что сокол без крильев 'A man without friends is like a falcon without wings'; Человек без друга - что земля без воды 'A man without a friend is like a land without water'; Без друга на душе вьюга 'There is a blizzard in the soul without a friend'; Верный друг лучше сотни слуг 'A faithful friend is better than hundreds of servants'; Без друга в жизни туго 'Without a friend life is tough'; Друг за друга стой - вьиграешь бой 'Defend each other and win the battle'; Сам погибай, а товарища выручай 'Die yourself, but help your comrade'; Врагу не кланяйся, а товарища выручай 'Do not bow to the enemy, but help a comrade'; Больше той любви не бывает,

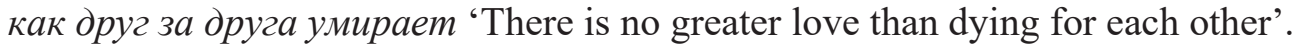

The value system of two peoples is revealed especially clearly through analyzing English and Russian proverbs of this group. This system is caused by various extralinguistic factors: the history, way of life, climate, etc. Comparisons and contradictions lay at the heart of their figurative structure. So, in English proverbs friendship is compared to an unsinkable ship, to phosphorus that shines brightly in the dark, to the 
best acquisition, to a cure for disease. The last proverb has a unique meaning, revealing the mentality of the British, who are very wary of strangers and maintain a distance in communication. In Russian proverbs, friendship is compared to powerful roots of a tree, to ценный клад 'valuable treasure'; a friend is more important than money, more important than сотни слуг 'hundreds of servants.' Russian proverbs use the vocabulary related to nature: земля без воды 'land without water', вьюга 'blizzard', ornithonym сокол 'falcon' as well as vernacular words like туго 'tough'. The penultimate three proverbs are imperative sentences by its syntactic structure and contain a call to help out a comrade in a battle at the expense of one's life. The readiness of friends to die for each other is also proclaimed as the highest manifestation of friendship in the last proverb. Its rhythmic organization helps to deepen the semantic content. These proverbs have a unique meaning; they reflect the mentality of a Russian warrior man, for whom mutual help and self-sacrifice in a battle guarantee a victory.

Comparison of the proverbs of this group shows that English proverbs are more likely bookish in nature and use neutral vocabulary, while Russian ones are more closely related to folklore: they include vocabulary, relating to nature and peasant life; use folk poetry and rhyming words. Russian proverbs reflect the mentality of a person, coming from peasantry. Analyzing the semantic construction of phrases, we see that English proverbs represent a friend as a kind of acquisition, an addition to an independent, self-sufficient person: these are images of a friend and friendship as medicine, lamp in the dark, etc. In Russian proverbs a friend is considered a part of some unity without which a person is no longer complete. This idea is emphasized by comparisons of a person without friends to a bird without wings, to a tree without roots. A significant part of Russian proverbs of this group is built on a comparison with negative model. In English proverbs, on the contrary, we see comparisons with positive model: what is a life of a person with a friend like. This observation, made by comparing the material, shows us that the British tend to be individualists and have a firm understanding of privacy.

The fourth implementation is naturally connected to the previous ones, representing classification of friendship types. It includes the most important issue, in which each individual is personally interested: what kind of friendship will be the most lasting, which kind of friendship is considered "real". Aristotle in "Nicomachean Ethics" gives his classification of types of friendship: utilitarian (friendship for the sake of any benefit), hedonistic (friendship for the sake of pleasure) and perfect (based on internal virtue and the corresponding likeness of friends) [36. P. 222223]. The first two types of friendship are imperfect and short-lived (disappear as soon as the basis for friendship disappears), the third type of friendship, based on internal qualities (virtues that are constant for Aristotle), is perfect both in essence and because of durability.

Temporary forms of friendship are reflected in both English and Russian proverbs. When good cheer is lacking our friends will be packing; No longer pipe, no longer dance; He that has a full purse never wanted a friend; In time of prosperity friends will be plenty. This English proverbs correspond to Russian ones: В paдости cыциут, в горе забудут 'In joy they seek, in grief they forget'; Хлеба нет, так и 
друзей не бывало 'If there is no bread, then friends are gone'; Eсть брага да пирожки, так есть други и дружки 'If there is home brew and pies, so there are friends and pals'; Плохой друг - что тень: в солнечный день не отвяжешься, $а$ в ненастный не найдешь 'A bad friend is like a shadow: on a sunny day you can not get rid of him, but on a rainy day you cannot find him'; У кого мошна полна, у того и друзей хватает 'He who has a full purse, has enough friends'.

The comparison of English and Russian proverbs of this group reveals subtle shades of meaning. The first parts of the English and Russian proverbs He that has a full purse... and $У$ кого мошна полна... 'He who has a full purse' are very close in figurative meaning and lexical components. However, the second part of the proverbs expresses different meanings. In the English proverb one who has money never wanted a friend. The Russian proverb manifests another meaning: one who has money ( $y$ того) друзей хватает 'he has enough friends'. The Russian proverb once again, albeit in an ironic way, emphasizes the need for friends in a person's life (even if their presence here is determined by selfish interest), while in the English proverb availability of money overrides the very need for friends. British individualism is opposed to the collectivism of Russian people. Russian proverbs are more figurative and expressive due to the oppositions and lexical antonyms: в радости - в горе 'in joy in grief', в солнечный день — в ненастныци день 'on a sunny day — on a rainy day'; due to expressive comparisons: плохой друг - что тень 'a bad friend is like a shadow'; through the use of diminutive suffixes: дружки 'pals', пирожки 'cakes'. In Russian proverbs human actions are compared to natural phenomena, which probably indicate the affinity of a Russian man to nature.

The true, reliable friendship is the treasure; its necessity is postulated by proverbs of both peoples. Assuming the possibility of a long-term, reliable friendship, it is necessary to determine the way to distinguish it from unreliable (fake) friendship. The answer to this question is given by proverbs, which say that "you can only understand who is your friend and who is your enemy when you face problems and difficulties". This group contains the following English proverbs: A friend in need is a friend indeed; Calamity is man's true touchstone; Prosperity makes friends and adversity tries them; Suffering for a friend doubleth friendship; In need one sees who his friend is; A friend is never known till a man have need. They correspond to the following Russian proverbs: Друзья познаются в беде 'Friends become known in trouble'; Без беды друга не узнаешь 'You will not get to know your friend without trouble'; Друг познается при рати да при беде 'A friend is known in a battle and in trouble'; Конь узнается при горе, а друг при беде 'A horse is known upon the mountain, and a friend in trouble'; Друг в беде - друг вдвойне 'A friend in need is twice a friend'; Кто друга в беде покидает, тот сам в беду попадает 'Who leaves a friend in need, he himself gets into trouble'. We see that most of the English proverbs are more neutral in lexical components, more aphoristic, edificatory, less expressive except for the proverb A friend in need is a friend indeed, that stands apart with its expressiveness and deserves a special attention. In this proverb, we observe the so-called phenomenon of "paronymic attraction", i.e. convergence of similarly sounding words, which leads to the effect of "false etymologization": indeed <in deed [37. P. 84]. The 
semantic volume of the proverb expands due to this fact. Most of the Russian proverbs of this group are also rather neutral lexically, but several of them are more dramatic: the one in which a friend is tested not only в беде 'in trouble', but also в рати (a lexical archaism that means 'battle'). The proverb with a zoonym конь 'horse' expands expressiveness due to expressive comparison.

The fifth implementation of the conception of friendship is closely related to the previous one. The essence of reliable true friendship is revealed in a group of proverbs about old and new friends. This group includes the following English proverbs: Before you make a friend eat a bushel of salt with him; Old friends and old wine are best; Make new friends but keep the old for one is silver and the other is gold; Old tunes are sweetest, old friends are surest; Old friends are better than new ones. A lot of synonymous Russian proverbs with the same meaning can be given: Человека узнаешь, когда пуд соли с ним съешь 'You will know a person when you eat a pood of salt with him'; Человека узнаешь, когда из семи печек с ним щии похлебаешь 'You will know a person when you eat cabbage soup out of seven stoves with him'; Не узнавай друга в три дня, узнавай в три года 'Do not get to know a friend in three days, get to know him in three years'; Hовых друзей наживай, а старых не забывай / не теряй 'Make new friends, but don't forget / don't lose old friends'; Вешь хороша пока нова, а друг - когда старый 'The thing is good while it is new, and the friend is good when he is old'; Cтарый друг лучше новых двух 'An old friend is better than two new ones'; Друг не испьтанный, что орех неколотый 'A friend not time-tested is like a nut not chopped'. The first English and the first Russian proverbs are partial equivalents, their figurative meaning coincides: "to experience friendship you need to eat a lot of salt" (pood / bushel of salt symbolizes a long period of time, spent together in various activities, especially in consentient labour). They are distinguished by its construction: in the English proverb, the main sentence is an imperative, and in the Russian one the sentence is indefinite-personal. According to E.V. Ivanova, “... motivation is more peculiar for the English proverbs; they encourage a person to take active actions or, on the contrary, prohibit them." [13. P. 190191]. It is expressed by the greater frequency of using imperative sentences. The same meaning is conveyed by another Russian proverb Человека узнаешь, когда из семи печек с ним щи похлебаешь, which reflects characteristic household details of the life of Russian people (nечь 'stove'), Russian food ( щзи 'cabbage soup'), contains a common word (похлебаешь 'eat'), which indicates its peasant origin. In the proverb Друг не испьтанныли, что орех неколотылй 'A friend not time-tested is like a nut not chopped' we see an unexpected comparison. All these features along with rhythmic organization and rhyming words make Russian proverbs more expressive. The comparing of English and Russian proverbs of this group reveals subtle shades of meaning. So, in the English proverbs old friends are compared to old wine, to gold and old melodies; in the Russian ones this meaning is revealed through striking contrasts новая вещь — старый друг 'new thing — old friend' and comparisons cmaрый друг лучше новых двух 'an old friend is better than two new ones'. The different lexical components of these proverbs indicates a different figurative thinking of the English and Russian peoples, however, the general meaning can be traced in both cases. We see that friendship is a result of coping with challenges together: either 
overcoming troubles or hard work / travelling together. The evidence of this is a bushel or $n y \partial$ 'pood' of salt. Both English and Russian proverbs appeal to time, matching friends according to the duration of friendship.

True friendship achieved with the help of hard work is not only valuable, but also a rare thing. The following group includes English and Russian proverbs that express folk wisdom: "You can be friends with many, but true friends should be few." So, the English proverb Books and friends should be few but good is unique by its figurative and motivational basis. It gains expressiveness due to the pictural comparison friends - books, which should be "few, but good." The English proverb A friend to all is a friend to none and the Russian one Всем брат - никому не брат "A brother to all is a brother to none' are very close in meaning and by the construction. The difference is that English proverb uses the word friend, and the Russian one uses бpam 'brother' instead, though the meaning of the latter is similar to "close friend", not "close relative". The studies of the British anthropologist, Robin Dunbar, conducted on extensive extralinguistic material, confirm our conclusion: the possible number of close friends is limited, the main factors of limitation are the time (that is needed to make friends and to communicate) and capabilities of the human brain [38].

The sixth implementation of the conception of friendship is close to the fifth one and thus is related to the others. At the same time, it reveals axiologically different aspects of the problem and thereby it strengthens the stability of the studied conception. True friendship is not limited to collaborative work and trials of life passed together.

The important group of proverbs conveys the peculiar meaning that "only friends can make a clear-eyed assessment of your behavior, indicate your strengths and weaknesses. It includes English proverbs: The eye of a friend is a good mirror; A friend's frown is better than foe's smile; All are not friends that speak fair; Only your real friends tell you when your face is dirty. They correspond to the following Russian proverbs: Лучше горькая правда, чем лесть врага 'Bitter truth is better than adulation of an enemу'; Не всяк друг, кто нас хвалит 'Not all are friends that praise us'; Друг спорит, а враг поддакивает 'Friend argues, and enemy assents'; Дружба крепка не лестью, а правдой и честью 'Friendship is strong not by flattery, but by truth and honour'; Не та рука, что только гладит, а и та, что за вихор таскает 'Not that friendly hand that just strokes, but the one that drags a tuft'; Не та собака кусает, что лает, а та, что молчит, да хвостом виляет 'Not that dog bites that barks, but that which is silent, but wags its tail'. Analyzing this group of proverbs, we see that both English and Russian proverbs provide their additional meaning. Their figurative and motivational basis and lexical components do not coincide completely. It is possible to consider counterparts: All are not friends that speak fair and Не всяк друг, кто нас хвалит. Two other English proverbs are based on double contraposition: open enemy - false friend and friend's frown - foe's smile. Russian proverb Лучше горькая правда, чем лесть врага is similar to the two aforementioned in its syntactic structure and is also based on double contraposition, but they are distinguished by lexical components. Frown and smile in English proverb figuratively denote arguing and assenting; this makes it close in its meaning to the other Russian proverb Друг спорит, а враг поддакивает, though they are distinguished by the syntactic structure. English proverb The eye of a friend is a good mirror does not have a direct Russian counterpart; the using of somatism eye increases its 
expressiveness. Another English proverb is also quite expressive due to the use of the face is dirty metaphor, which reflects bad features of character. Two distinctive Russian proverbs of this group are identical by their syntactic structure and represent folk-colloquial construction of the sentence. In one of them the idea of an enemy is hidden behind the somatism рука 'hand' that гладит 'strokes', and the idea of a friend is hidden behind a рука 'hand' that за чуб таскает 'drags by a tuft'. In the second Russian proverb of the same type we see the allegory. The behavior and the traits of the animal are transferred to the person. These proverbs are associated with Russian folklore and have peasant origin.

The same group includes English and Russian proverbs that have the meaning "a good friend speaks good behind the scenes": He is a good friend that speaks well of us behind our backs. The Russian language also has a proverb that partially conveys this meaning: Хороший друг в личо ругает, а за глаза хвалит 'A good friend scolds to one's face and praises behind the back'. Here is educative function of a true friend. A person, connected with him by mutual trust, will rather listen to his words and try to correct mistakes in some way. At the same time, "a friend is always the one who understands us, who sees us through our outer shell and acknowledges our innocence" [14. P. 97].

The seventh implementation of the conception of friendship is related to the previous ones. The following aspect of the conception generalizes the value of friendship. Both English and Russian proverbs manifest that friendship must be preserved and cherished, since it is not so easy to find a friend. This group includes an English proverb Friendship is like money, easier made than kept and corresponding Russian proverbs: Hет друга - ищи, а нашел - береги 'Seek for friend if you do not have one, and take care of him if you find him'; На деньги друга не купишь 'You can't buy a friend for money'; Не имей сто рублей, а имей сто друзей 'Do not have a hundred rubles, but have a hundred friends'; Дружба дороже денег 'Friendship is more expensive than money'. The English example derives from a quotation, that makes it more aphoristic. It is an extended sentence by its structure. Money here acts as a model for the object of discussion (friendship). The corresponding Russian proverb also includes the word money, but it is used not in the comparison, but in the lexical contraposition: friendship / friend is more valuable than money. Other Russian proverb of the same meaning Не имей сто рублей, а имей сто друзей is very expressive due to its structure (two imperative sentences in the form of the contraposition), due to detailed concept of "money" (сто рублей 'hundred rubles') and due to rhyming words (рублей - друзей). In English there is a proverb that expresses a similar meaning, but with significant clarification: A friend in court is better than a penny in purse. A friend in court here refers to a powerful friend. This proverb has no counterparts in the Russian language and reflects the mentality of an Englishman, for whom powerful friend is more valuable than money. This proverb characterizes the British as pragmatic people who appreciate not only the quality of friendship (true or not), but also traits of the friend himself.

The eighth implementation specifically represents the dynamics of friendship. The relevant aspects, correlated with all seven previous implementations, represent the concept of friendship in the scope of the "test to destruction". The following group includes proverbs about destruction and reconstruction of friendship: Patched 
up friendship seldom becomes whole again; Reconciled friendship is a wound ill salved; A broken friendship may be soldered, bur will never be sound. English proverbs correspond to Russian ones: Замиренныий друг ненадежен 'A reconciled friend is unreliable'; Дружба что стекло: сломаешь - не починишь 'Friendship is like glass: if you break it, you can't fix it'; Надсаженный конь, надломанный лук, да замиренный друг равно ненадежны 'An overstrained horse, a broken bow and a reconciled friend are equally unreliable'. Comparing proverbs we see that one English and two Russian proverbs contain a common lexical component reconciled замиренный. These proverbs are expressive due to figurative comparisons: reconciled friendship is compared to a wound ill salved in English and замиренньй друг 'reconciled friend' — to а надломленный лук 'cracked bow' and надсаженный конь 'overstrained horse' in Russian. Another vivid comparison дружба 'friendship' стекло 'glass' is used in another Russian proverb. English proverbs use more neutral metaphors concerning friendship: patched up, broken. Both English and Russian units of this group contain specific metaphors and reveal the figurative thinking of both linguistic and cultural ethnic groups in different ways. Following on the analysis of this group of proverbs, we conclude that friendship seems to be a rather fragile, inflexible kind of relationship. Despite the fact that it is "forged" in consentient labour, in battles and troubles, it looses its value after destruction and can not be "repaired". Let us return to Aristotle: if friendship has a constant, perfect foundation (i.e. is based on the virtue of friends and a mutual disinterested attitude towards each other), then it can end only after the death of friends. If it stopped earlier, therefore, its foundation was not perfect, because the attitude of one of the friends was not disinterested. Naturally, it is impossible to trust such a friend. If we assume the very possibility of developing a disinterested attitude to replace the former, self-serving one, then, probably, this could be resulted in a new friendship. The "glued together" old "friendship" is, in fact, a kind of relationship when both participants see the truth: that it is not true friendship or not a friendship at all, but for some (perhaps self-centered) reason they continue to communicate.

It is the disclosure of selfish motives that probably is the reason of the destruction of friendship. Following group of proverbs confirms this idea. It includes two English proverbs: Lend your money and lose your friend; Short debt make long friend. Corresponding Russian proverbs are: Хочешь потерять друга - дай ему в долг 'If уоu want to lose a friend, grant him a loan'; Дружба дружбой, а денежки врозь 'Friendship is friendship, but keep money apart'; В долг давать - дружбу терять 'То grant a loan to friend is to lose friendship'; Счет дружбе не помеха / Счет дружбь не nopmum 'Calculation is not a hindrance to friendship / Calculation doesn't spoil friendship'. The proverbs Lend your money and lose your friend and Xочешь nomeрять друга - дай ему в долг are partial equivalents, they are slightly distinguished by grammatical structure and the word order. Other Russian proverbs convey similar meaning by more expressive syntactic and lexical means, using words with diminutive suffixes (денежки 'money'), infinitive sentences (В долг давать - дружбу терять 'To grant a loan to friend is to lose friendship') and rhyming words (даваmb 'to grant' - терять 'to lose'). Describing this aspect of the conception of friendship, one cannot but give another English proverb with a specific meaning: Friends are all right when they don't interfere with you career. In Russian there is a proverb with the close 
meaning: Дружба дружбой, а служба службой 'Friendship is friendship, but duty is duty'. The comparison of these proverbs allows us to determine that they reflect the mentality of different classes. The English proverb is an aphorism, it contains a literary expression interfere with one's career, which reflects the worldview of an urban dweller, bureaucrat or salaried employee. Russian proverb is more neutral lexically, its expressiveness arises due to syntactic parallelism and rhythmic organization.

Our conclusions are consistent with previously obtained generalizations that were made in our recent works [39].

\section{Conclusion}

The performed analysis is generally summarized in two interrelated directions. Firstly, according to the goal, a system of implementations of the conception of friendship is revealed. Complexity of friendship, the interdependence of its positive and opposing negative sides is revealed only through the mutual interaction of these implementations (emphasis on unity and opposing desire for individualization, fragility, etc.). Secondly, the system of similarities and differences for the corresponding semantic groups of Russian and English proverbs is revealed. Implementations of the conception of friendship on the phraseological material of both languages are similar in many respects, but they also have certain differences. Friendship appears to be a valuable, hard-to-reach, fragile phenomenon. The comparative structural and semantic analysis of the proverbs of both languages showed that among them we can distinguish proverbs that are equivalent in meaning, as well as counterparts that manifest peculiar features of national character and mentality. English proverbs have more didactic and edifying character; they often use imperative sentences and rather neutral vocabulary. In the English proverbs we also noted the desire for individualization as a key feature which determines the other features of the English. This observation is partially consistent with the conclusions of anthropologists (K. Fox calls this central characteristic quality of the British social dis-ease [40]). Both English and Russian proverbs use rhythmic structures and rhyming words that actualize their meaning and contribute to their memorization, but Russian proverbs use them more often. Russian proverbs are more expressive through the use of folk-colloquial vocabulary and diminutive suffixes. Also we observe a closer connection of the Russian proverbs with the conceptual sphere of peasant life. The similarities and differences of English and Russian proverbs characterize clearly the mentality of the both peoples.

The practical significance of the results is the possibility of developing a new type of dictionary on their basis: "Friendship: The experience of cognitive-contrast lexicography." Thus the main directions for further research are the expansion of the theoretical foundations of cognitive lexicography and the addition of the conceptualization of friendship with data from languages other than Russian and English.

\section{References}

1. Neretina, S.S. \& Ogurtsov, A.P. (2010). Conception In New philosophical encyclopedia. In 4 vols. Moscow: Thought. Vol. 2. pp. 308-309. (In Russ.).

2. Vezhbitskaya, A. (2001). The juxtaposition of cultures through vocabulary and pragmatics: Monograph. A.D. Shmelev (Transl.). Moscow: Languages of Slavic culture. (In Russ.). 
3. Alefirenko, N.F. \& Skokova, T.N. (2017). Sense as a problem of intercultural communication In Linguistic aspects of intercultural communication. Rostov $\mathrm{n} /$ Don; Taganrog: SFU. pp. 9-37. (In Russ.).

4. Telia, V.N. (1996). Russian phraseology. Semantic pragmatic and linguocultural aspects. Moscow: Languages of Russian culture. (In Russ.).

5. Desai, A. \& Killick, E. (2010). The Ways of Friendship: Antropological Perspectives. Berghahn: Berghahn Books.

6. Svare, H. (2010). Philosophy of friendship. Moscow: Progress-Tradition. (In Russ.).

7. Aciobăniţei, M. (2012). Paremiological Aspects in the Construction of National Identity. Procedia - Social and Behavioral Sciences, 63, 276-282.

8. Ivanova, E.V. (2006). The world in English and Russian proverbs: Textbook. Saint Petersburg: Saint Petersburg State University. (In Russ.).

9. Arsentieva, E.F. (1989). Comparative analysis of phraseological units. Kazan: Publishing house of KazSU. (In Russ.).

10. Voropaeva, V.A. (2007). Comparative characteristic of English, German and Russian paroemias and phraseological units expressing tolerance [dissertation]. Moscow. (In Russ.).

11. Smith, E.E. (2019). The power of meaning. Create a life that matters. Moscow: AST. (In Russ.).

12. Maslow, A. (2018). Motivation and personality. Moscow, Saint Petersburg: Peter. (In Russ.).

13. Beer, B. \& Gardner, D. (2015). Friendship In Anthropology of International Encyclopedia of the Social \& Behavioral Sciences. 2nd edition. Vol. 9. Oxford: Elsevier. pp. 425-431.

14. Alberoni, F. (1991). Friendship and love. Moscow: Progress. (In Russ.).

15. Bunnell, T., Yea, S., Peake, L., Skelton, T. \& Smith, M. (2012). Geographies of Friendships. Progress in Human Geography, 36 (4), 490-507.

16. Avakimova, E.A. \& Saychenko, V.V. (2019). The motivational range of "children's themes" in modern Russian literature In Actual problems of modern philology: theory, practice, development prospects. Krasnodar: KubSU. pp. 225-227. (In Russ.).

17. Stepanov, Y.S. (1997). Constants Dictionary of Russian culture. Research experience. Moscow: RAS; School "Languages of Russian Culture". (In Russ.).

18. Dementiev, V.V. (2007). Heart to heart conversation In Anthology of speech genres: everyday communication. Moscow: Labyrinth. pp. 231-245. (In Russ.).

19. Lukashkova, O.Y. (2003). The concept of "enemy" in modern Russian and American media In Language and national consciousness. Voronezh: Istoki. pp. 156-161. (In Russ.).

20. Khizova, M.A. (2005). The concept of "friendship" in Russian and English linguistic cultures (based on Russian and English languages) [dissertation]. Volgograd. (In Russ.).

21. Delaney, T. \& Madigan, T. (2017). Friendship and Happiness: And the Connection Between the Two. McFarland.

22. Stinson, B. (2019). Bro Code. Moscow: EKSMO. (In Russ.).

23. Burmistrova, L.V. (2017). Semantic characteristics of comic proverb In Language. Text. Discourse. Stavropol: SKFU. pp. 313-319. (In Russ.).

24. Shmelev, A.D. (2004). Friendship in the Russian language world-image In Sacred meanings. Word. Text. The culture. Moscow: YASK. pp. 704-715. (In Russ.).

25. Čermák, F. (2018). Friends and friendship in proverbs. Linguistica Brunensia, 66(1), 73-85.

26. Komarova, Z.I. (2017). Methodology, methods, technique and technology of scientific research in linguistics. Moscow: Nauka; Flinta. (In Russ.).

27. Emirova, A.M. (2019). Modern Crimean Tatar lexicography. Simferopol: Nauchnyi mir. (In Russ.).

28. Dal, V.I. (2009). Proverbs of the Russian people. Moscow: Russian language Media. (In Russ.).

29. Zhukov, V.P. (1990). Dictionary of Russian proverbs and sayings. Moscow. (In Russ.).

30. Dictionary common English proverbs (1990). M.V. Bukovskaya, S.I. Vyaltseva, Z.I. Dubyanskaya et al (eds.). Moscow: Russian language. (In Russ.).

31. Longman Contemporary English Dictionary (2001). Harlow (GB): Longman.

32. Smith, W.G. (2008). The Oxford dictionary of English proverbs. Oxford.

33. Dubrovskaya, O.G. (2002). Russian and English proverbs as cultural units. Tyumen. (In Russ.). 
34. Sergeeva, A.V. (2006). Russians: stereotypes of behavior, traditions, mentality. Moscow: Flinta-Nauka. (In Russ.).

35. Tönnies, F. (2002). Community and society. Saint-Petersburg: Vladimir Dal. (In Russ.).

36. Aristotle (1983). Works in four volumes. Volume 4. Moscow: Mysl'. (In Russ.).

37. Eliseeva, V.V. (1988). English paremias: some features of the content plan In Semantics and pragmatics of language in the dialogue of cultures. Samara. pp. 82-86. (In Russ.).

38. Dunbar, R.I.M. (2018). The Anatomy of Friendship. Trends of Cognitive Sciences, January 2018, 22(1), 32-51.

39. Orlova, T.G. (2018). Comparative structural and semantic analysis of English and Russian proverbs expressing the moral and ethical semantic dominant "teaching, knowledge, wisdom". Historical and socio-educational thought, 10(2-2), 148-156. doi: 10.17748/20759908-2018-10-2/2-148-156. (In Russ.).

40. Fox, K. (2014). Watching the English. The Hidden Rules of English Behavior. Hodder.

\section{Библиографический список}

1. Неретина С.С., Огуриов А.П. Концепция // Новая философская энциклопедия. В 4 тт. М.: Мысль, 2010. Т. 2. С. 308-309.

2. Вежбицкая A. Сопоставление культур через посредство лексики и прагматики: Монография / Пер. с англ. и предисл. А.Д. Шмелева. М.: Языки славянской культуры, 2001. C. 272.

3. Алефиренко Н.Ф., Скокова Т.Н. Смысл как проблема межкультурной коммуникации // Лингвистические аспекты межкультурной коммуникации. Ростов н/Д; Таганрог: ЮФУ, 2017. C. $9-37$.

4. Телия В.Н. Русская фразеология. Семантический прагматический и лингвокультурологический аспекты. М.: Языки русской культуры, 1996.

5. Desai A., Killick E. The Ways of Friendship: Antropological Perspectives. Berghahn: Berghahn Books, 2010.

6. Сваре X. Философия дружбы. М.: Прогресс-Традиция, 2010.

7. Aciobăniţei M. Paremiological Aspects in the Construction of National Identity // Procedia Social and Behavioral Sciences. 2012. Vol. 63. C. 276-282.

8. Иванова E.B. Мир в английских и русских пословицах: Учебное пособие. СПб: СПбГУ, 2006.

9. Арсентьева Е.Ф. Сопоставительный анализ фразеологических единиц. Казань: Издво КазГУ, 1989.

10. Воропаева В.А. Сопоставительная характеристика английских, немецких и русских паремий и фразеологизмов, выражающих толерантность: Автореф. дис. ... канд. филол. наук. M., 2007.

11. Смит Э.Э. Сила смысла. Создай жизнь, которая имеет значение. М.: АСТ, 2019.

12. Маслоу А. Мотивация и личность. М.; СПб.: Питер, 2018. С. 400.

13. Beer B., Gardner D. Beer B., Gardner D. Friendship, Anthropology of // International Encyclopedia of the Social \& Behavioral Sciences, $2^{\text {nd }}$ edition, Vol. 9. Oxford: Elsevier. C. $425-431$.

14. Альберони Ф. Дружба и любовь. М.: Прогресс, 1991.

15. Bunnell T., Yea S., Peake L., Skelton T., Smith M. Geographies of Friendships // Progress in Human Geography. 2012. no 36 (4). C. 490-507.

16. Авакимова E.A., Сайченко В.В. Мотивный диапазон «детской темы» в современной русской литературе // Актуальные вопросы современной филологии: теория, практика, перспективы развития. Краснодар: КубГУ, 2019. С. 225-227.

17. Степанов Ю.С. Константы. Словарь русской культуры. Опыт исследования. М.: РАН; Школа «Языки русской культуры», 1997.

18. Дементьев В.В. Разговор по душам // Антология речевых жанров: повседневная коммуникация. М.: Лабиринт, 2007. С. 231-245.

19. Лукашкова О.Ю. Концепт «враг» в современных российских и американских СМИ // Язык и национальное сознание. Воронеж: Истоки, 2003. С. 156-161. 
20. Хизова М.A. Концепт «дружба» в русской и английской лингвокультурах (на материале русского и английского языков): Автореф. дис. ...канд.филол.наук. Волгоград, 2005.

21. Delaney T., Madigan T. Friendship and Happiness: And the Connection Between the Two. McFarland, 2017.

22. Стинсон Б. Кодекс братана. М.: ЭКСМО, 2019.

23. Бурмистрова Л.В. Семантические характеристики комических пословиц // Язык. Текст. Дискурс. Ставрополь: СКФУ, 2017. С. 313-319.

24. Шмелев А.Д. Дружба в русской языковой картине мира // Сокровенные смыслы. Слово. Текст. Культура. М.: ЯСК, 2004. С. 704-715.

25. Čermák F. Friends and friendship in proverbs // Linguistica Brunensia. 2018. Vol. 66. Iss. 1. C. $73-85$.

26. Комарова З.И. Методология, методы, методика и технология научных исследований в лингвистике. М.: Наука; Флинта, 2017.

27. Эмирова А.М. Современная крымско-татарская лексикография. Симферополь: Науч. мир, 2019.

28. Даль В.И. Пословицы русского народа. М.: Русский язык, Медиа, 2009.

29. Жуков В.П. Словарь русских пословиц и поговорок. М., 1990.

30. Словарь употребительных английских пословиц // М.В. Буковская, С.И. Вяльцева, 3.И. Дубянская и др. М.: Русский язык, 1990.

31. Longman Contemporary English Dictionary. Harlow (GB): Longman, 2001.

32. Smith W.G. The Oxford dictionary of English proverbs. Oxford, 2008.

33. Дубровская О.Г. Русские и английские пословицы как культурологические единицы. Тюмень, 2002.

34. Сергеева А.B. Русские: стереотипы поведения, традиции, ментальность. М.: Флинта. Наука, 2006.

35. Теннис Ф. Общность и общество. СПб.: Владимир Даль, 2002.

36. Аристотель. Сочинения в четырех томах. Том 4. М.: Мысль, 1983.

37. Елисеева В.В. Английские паремии: некоторые особенности плана содержания // Cемантика и прагматика языка в диалоге культур. Самара, 1988. С. 82-86.

38. Dunbar R.I.M. The Anatomy of Friendship // Trends of Cognitive Sciences. January 2018. Volume 22. Number 1. C. 32-51.

39. Орлова Т.Г. Сопоставительный структурно-семантический анализ английских и русских пословиц, выражающих морально-этическую смысловую доминанту «учение, знание, мудрость» // Историческая и социально-образовательная мысль. 2018. Том. 10. № 2-2. C. 148 - 156. doi: 10.17748/2075-9908-2018-10-2/2-148-156.

40. Fox K. Watching the English. The Hidden Rules of English Behaviour. Hodder, 2014.

\section{Information about the author:}

Tatiana G. Orlova, Candidate of Philological Sciences, Associate Professor of the Department of Foreign Languages, Faculty of Humanities and Social Sciences, Peoples' Friendship University of Russia (RUDN University); scientific interests: comparative linguistics, phraseology, paroemiology, semantics; e-mail: orlova-tg@rudn.ru. Web of Science ResearcherID A-6149-2017. Scopus Author ID: 57201723102. ORCID: https://orcid.org/0000-0002-2777-3930

\section{Сведения об авторе:}

Орлова Татьяна Геннадьевна, кандидат филологических наук, доцент кафедры иностранных языков факультета гуманитарных и социальных наук РУДН; научные интересы: сравнительное языкознание, паремиология, фразеология, семантика; e-mail: orlova-tg@rudn.ru. eLibrary SPIN-код: 6686-7256. ORCID: https://orcid.org/0000-0002-2777-3930 